\title{
Emergency Slaughter of Cattle due to Immobility
}

\author{
V. PIŠTĚKOVÁ, I. OŠŤÁDALOVÁ, J. SEDLÁKOVÁ, P. TOMANOVÁ, I. BEDÁŇOVÁ \\ Department of Veterinary Public Health and Toxicology, University of Veterinary \\ and Pharmaceutical Sciences, Brno, Czech Republic
}

Received May 21, 2004

Accepted October 26, 2004

\begin{abstract}
Pištěková V., I. Oštádalová, J. Sedláková, P. Tomanová, I. Bedáňová: Emergency Slaughter of Cattle due to Immobility. Acta Vet Brno 2004, 73: 533-538.

The objective of this work was to determine the most common causes and the trend in the development of emergency slaughters of cattle due to immobility. Emergency slaughters due to immobility of cows, heifers, bulls and calves were monitored in a selected facility in the region of South Bohemia in the period between 1997 and 2002. The frequencies of the individual causes were recorded. The most common causes of emergency slaughters due to immobility were damage to the locomotor apparatus that represented $72.2 \%$ in cows, $87.2 \%$ in heifers, $92.4 \%$ in bulls, $82.5 \%$ in calves and it was also found that the most common causes are injuries to the limbs, joint and claw inflammations, pelvic injuries and paresis of hind limbs. With regard to the development trends, an increase in the disorders of the locomotor apparatus has been noted in cows (index 1.21), in heifers (index 1.13) and in bulls (index 1.16). This increase was found to be statistically significant in cows $(P=0.001)$; the increase was not statistically significant in heifers and in bulls. Other causes of emergency slaughters due to immobility that derive from the general bad health condition of the organism displayed a decreasing trend in cows, heifers and bulls. In calves, an increase for the disorders of the locomotor apparatus was not recorded (index 0.96). Our study indicates that the disorders of the locomotor apparatus are the major causes of emergency slaughters due to immobility in cattle.
\end{abstract}

Locomotor apparatus diseases, limb injuries, joint and claw inflammations, pelvic injuries, paresis of the hind limbs, cows, heifers, bulls, calves

Animal immobility may have various causes. Usually, it is the result of an ongoing disease that may affect solely the locomotor apparatus or that can have a general impact. B room and Corke (2002) write that in dairy cattle, the mobility of animals is very frequently affected by various disorders of the limbs. Bergsten (2001) and Logue et al. (1993) present that lesions on the limbs of dairy cattle are the most usual cause of limited mobility in cattle. Immobility in the different categories of cattle as a result of handling these animals at farms, during transport and at slaughter facilities may be expressed by an increase in the number of emergency slaughters. The limited mobility to immobility in cows, heifers, bulls and calves can bring on the increased number of emergency slaughters due to immobility in these cattle categories. Emergency slaughters of cattle in the Czech Republic were studied by Večerek et al. (2003a). The diseases of the locomotor apparatus were identified as a serious issue and they were the most common cause of emergency slaughters of cattle: $35.30 \%$ in cows, $43.07 \%$ in heifers, and $58.27 \%$ in bulls. Only in calves, the most common cause was found to be the diseases of respiratory system. The diseases of the locomotor apparatus presented $21.17 \%$. Cattle are food animals whose pathological findings at a regular slaughter are so common that the rate of suitability of the carcasses for consumption is the lowest in comparison to the other food animal species. According to Kozák et al. (2002), they are $63.76 \%$ in calves, $79.48 \%$ in cows, $92.49 \%$ in heifers and $95.52 \%$ in bulls. Večerek et al. (2003b) published that the slaughter facility findings in cattle carcasses in the Czech Republic are $4.45 \%$ of the non-infectious origin and $0.15 \%$ of the infectious origin 
while the highest frequency is present in the sensory changes in the meat (2.56\%). Similar conclusions were drawn also for pigs (Kozák et al. 2003). Večerek et al. (2003c, 2004) have dealt with slaughter facility findings on the organs of cattle and pigs in the Czech Republic; the most frequent findings resulting in unsuitability for consumption were done on the lungs. Monitoring of the slaughter facility findings as part of the veterinary examination of food animals and meat in cattle was undertaken by Julini (1993), Giaccone et al. (1994) and Bis s et al. (1994).

Cattle immobility that leads to emergency slaughters may have various causes. Determination of the individual causes and especially the frequency of emergency slaughters due to these causes may point to the character of treatment and handling of various categories of cattle. It may thus be a good basis for the measures that could lead to the improvement of the care of food animals in farms, during their transport to the slaughter facilities and also during the handling of the animals at the slaughter facility site. It could lead to a reduction of the numbers of emergency slaughtered cattle due to immobility and thus to a reduction of the frequency of emergency slaughters of cattle at slaughter facilities.

The objective of this work was to determine the most common causes and the trend in the development of emergency slaughters of cattle due to immobility.

\section{Materials and Methods}

In the selected slaughter facility in the region of South Bohemia, emergency slaughters due to immobility of cows, heifers, bulls and calves were monitored in the years 1997 to 2002 . The facility enabled both emergency and regular slaughter of cows, heifers, bulls, calves, sheep, goats and horses in the total volume of 2500 to 3000 large stock animal unit per year. The distance of the farms was 3 to $40 \mathrm{~km}$, with few exceptions exceeding this limit. The facility was designed only for slaughtering, meat was shipped in halves and quarters. In this facility, the frequency of the individual causes of emergency slaughter were recorded by the following scheme: pelvic injuries (namely the rupture of the pelvic symphysis), contusion of the spine or limbs, paresis of the hind limbs, limb injuries (including fractures, luxations, distortions, wounds, swellings, abscesses, ruptures of the joint ligaments and tendons), inflammations of joints and claws (including the tarsus and carpus inflammations, panaritium, cheilodermatitis, phlegmons), selection and technopathy, cachexia and disorders of the alimentary system, ataxia, tetany, circulation disorders including the heart insufficiencies, post-partum complications, other (including for example metritis, mastitis, nephritis, encephalopathies, etc.). The absolute and relative frequencies (\%) for the individual causes were calculated from the total number of emergency slaughtered animals due to immobility in the whole period between 1997 and 2002. For the comparison of the long-term development trend, the actual and relative frequencies for the $1^{\text {st }}$ period (1997 to 1999) and for the $2^{\text {nd }}$ period (2000 to 2002) were counted and both period were compared on the basis of the index of the ratio of the relative number of the $2^{\text {nd }}$ period to the relative number of the $1^{\text {st }}$ period. In case that the index exceeded 1 , then the monitored parameter had an increasing trend. In case the index equalled 1 then the monitored parameter displayed neither increase nor decrease and in cast the index was found to be less than 1 then there is a decrease in the monitored parameter. Statistical comparison of the results was done with the use of the Unistat software (Unistat Statistical Package - Unistat Limited) with the module for comparison of frequencies using $\chi^{2}$ test.

\section{Results}

The causes of emergency slaughter of cattle due to immobility reasons and the frequencies of emergency slaughters in the whole period of 1997 to 2002 are presented in Table 1 for the individual cattle categories.

The results in Table 1 show that the most common causes of emergency slaughters due to immobility was damage to the locomotor apparatus that was $72.2 \%$ in cows, $87.2 \%$ in heifers, $92.4 \%$ in bulls and $82.5 \%$ in calves.

The trend in the frequencies of the individual causes of emergency slaughters of cattle due to immobility represented as the index of the ratio of the $2^{\text {nd }}$ period (the period between 2000 and 2002) relative frequency to the $1^{\text {st }}$ period (the period between 1997 and 1999) relative frequency is given in the Tables $2,3,4$, and 5. 
Table 1

The causes and the frequencies of emergency slaughters of cattle due to immobility reasons in the whole period of $1997-2002$

\begin{tabular}{|l|r|r|r|r|r|r|r|r|}
\hline \multirow{2}{*}{} & \multicolumn{2}{|c|}{ Cows } & \multicolumn{2}{|c|}{ Heifers } & \multicolumn{2}{c|}{ Bulls } & \multicolumn{2}{c|}{ Calves } \\
\cline { 2 - 10 } & freq. & \multicolumn{1}{|c|}{$\%$} & freq. & \multicolumn{1}{c|}{$\%$} & freq. & \multicolumn{1}{c|}{$\%$} & freq. & $\%$ \\
\hline Pelvic injuries & 52 & 10.70 & 12 & 21.82 & 6 & 15.38 & 2 & 8.70 \\
\hline Contusions of the spine and limbs & 18 & 3.70 & 3 & 5.45 & 2 & 5.13 & 1 & 4.35 \\
\hline Paresis of the hind limbs & 94 & 19.34 & 8 & 14.55 & 9 & 23.08 & 5 & 21.74 \\
\hline Limb injuries & 86 & 17.70 & 23 & 41.82 & 15 & 38.46 & 6 & 26.09 \\
\hline Joint and claw inflammations & 101 & 20.78 & 2 & 3.64 & 4 & 10.26 & 5 & 21.74 \\
\hline Selection and technopathy & 6 & 1.23 & 3 & 5.45 & 0 & 0.00 & 1 & 4.35 \\
\hline Cachexia and GIT disorders & 19 & 3.91 & 0 & 0.00 & 1 & 2.56 & 0 & 0.00 \\
\hline Ataxia & 12 & 2.47 & 2 & 3.64 & 2 & 5.13 & 2 & 8.70 \\
\hline Tetany & 1 & 0.21 & 0 & 0.00 & 0 & 0.00 & 0 & 0.00 \\
\hline Circulation disorders & 6 & 1.23 & 2 & 3.64 & 0 & 0.00 & 1 & 4.35 \\
\hline Post-partum complications & 85 & 17.49 & 0 & 0.00 & 0 & 0.00 & 0 & 0.00 \\
\hline Other & 6 & 1.23 & 0 & 0.00 & 0 & 0.00 & 0 & 0.00 \\
\hline Total & 486 & 100.00 & 55 & 100.00 & 39 & 100.00 & 23 & 100.00 \\
\hline Locomotor apparatus total & 351 & 72.22 & 48 & 87.27 & 36 & 92.31 & 19 & 82.61 \\
\hline
\end{tabular}

Table 2

The trend of the incidence of the individual causes of emergency slaughters in cows due to immobility

\begin{tabular}{|c|c|c|c|c|c|c|}
\hline \multirow[t]{2}{*}{ Cows } & \multicolumn{2}{|c|}{$\begin{array}{c}\text { Period I } \\
1997-1999 \\
\end{array}$} & \multicolumn{2}{|c|}{$\begin{array}{c}\text { Period II } \\
2000-2002\end{array}$} & \multirow[t]{2}{*}{ index } & \multirow[t]{2}{*}{$P$} \\
\hline & frequency & $\%$ & frequency & $\%$ & & \\
\hline Pelvic injuries & 33 & 14.5 & 19 & 7.4 & 0.51 & 0.011 \\
\hline Contusions of the spine and limbs & 8 & 3.5 & 10 & 3.9 & 1.10 & 0.831 \\
\hline Paresis of the hind limbs & 46 & 20.2 & 48 & 18.6 & 0.92 & 0.662 \\
\hline Limb injuries & 26 & 11.4 & 60 & 23.3 & 2.04 & 0.001 \\
\hline Joint and claw inflammations & 35 & 15.4 & 66 & 25.6 & 1.67 & 0.006 \\
\hline Selection and technopathy & 2 & 0.9 & 4 & 1.6 & 2.00 & 0.502 \\
\hline Cachexia and GIT disorders & 14 & 6.1 & 5 & 1.9 & 0.32 & 0.017 \\
\hline Ataxia & 10 & 4.4 & 2 & 0.8 & 0.18 & 0.011 \\
\hline Tetany & 0 & 0.0 & 1 & 0.4 & - & - \\
\hline Circulation disorders & 3 & 1.3 & 3 & 1.2 & 0.88 & 0.879 \\
\hline Post-partum complications & 48 & 21.1 & 37 & 14.3 & 0.68 & 0.052 \\
\hline Other & 3 & 1.3 & 3 & 1.2 & 1.00 & 0.879 \\
\hline Total & 228 & 100.0 & 258 & 100.0 & & \\
\hline Locomotor apparatus total & 148 & 64.9 & 203 & 78.7 & 1.21 & 0.001 \\
\hline
\end{tabular}

Legend: $P=$ statistical significance; Index $=$ the ratio of the relative frequencies of the incidence of emergency slaughters due to immobility for the $1^{\text {st }}$ period (1997 to 1999) and the $2^{\text {nd }}$ period (2000 to 2002); - = a very small frequency was found to be sufficient for the calculation of the index and the statistical significance

With regard to the trend of the development of the causes of emergency slaughters due to immobility, a significant role is played by the finding that it is damage to the locomotor apparatus that shows an increasing trend in the incidence of these reasons for emergency slaughters in cows (index 1.21). This increase was found to have been significant $(P=0.001)$. It was mostly represented by limb injuries (index 2.04, $P=0.001$ ) and joint and claw inflammations (index 1.67, $P=0.006$ ). In heifers, an increase of incidence of emergency slaughters due to damage to locomotor apparatus (index 1.13) was detected, as well as in bulls (index 1.16). This increase was not proved to be significant. In calves, an increase in the emergency slaughters due to damage to the locomotor apparatus was not found (index 0.96). 
Table 3

The trend of the incidence of the individual causes of emergency slaughters in heifers due to immobility

\begin{tabular}{|c|c|c|c|c|c|c|}
\hline \multirow[t]{2}{*}{ Heifers } & \multicolumn{2}{|c|}{$\begin{array}{c}\text { Period I } \\
\text { 1997-1999 }\end{array}$} & \multicolumn{2}{|c|}{$\begin{array}{c}\text { Period II } \\
\text { 2000-2002 }\end{array}$} & \multirow[t]{2}{*}{ index } & \multirow[t]{2}{*}{$P$} \\
\hline & frequency & $\%$ & frequency & $\%$ & & \\
\hline Pelvic injuries & 8 & 21.6 & 4 & 22.2 & 1.03 & 0.959 \\
\hline Contusions of the spine and limbs & 2 & 5.4 & 1 & 5.6 & 1.03 & 0.982 \\
\hline Paresis of the hind limbs & 6 & 16.2 & 2 & 11.1 & 0.69 & 0.614 \\
\hline Limb injuries & 14 & 37.8 & 9 & 50.0 & 1.32 & 0.391 \\
\hline Joint and claw inflammations & 1 & 2.7 & 1 & 5.6 & 2.06 & 0.596 \\
\hline Selection and technopathy & 3 & 8.1 & 0 & 0.0 & - & - \\
\hline Cachexia and GIT disorders & 0 & 0.0 & 0 & 0.0 & - & - \\
\hline Ataxia & 2 & 5.4 & 0 & 0.0 & - & - \\
\hline Tetany & 0 & 0.0 & 0 & 0.0 & - & - \\
\hline Circulation disorders & 1 & 2.7 & 1 & 5.6 & 2.06 & 0.596 \\
\hline Post-partum complications & 0 & 0.0 & 0 & 0.0 & - & - \\
\hline Other & 0 & 0.0 & 0 & 0.0 & - & - \\
\hline Total & 37 & 100.0 & 18 & 100.0 & & \\
\hline Locomotor apparatus total & 31 & 83.8 & 17 & 94.4 & 1.13 & 0.266 \\
\hline
\end{tabular}

Legend: $P=$ statistical significance; Index $=$ the ratio of the relative frequencies of the incidence of emergency slaughters due to immobility for the $1^{\text {st }}$ period (1997 to 1999) and the $2^{\text {nd }}$ period (2000 to 2002); - = a very small frequency was found to be sufficient for the calculation of the index and the statistical significance

Table 4

The trend of the incidence of the individual causes of emergency slaughters in bulls due to immobility

\begin{tabular}{|c|c|c|c|c|c|c|}
\hline \multirow[t]{2}{*}{ Bulls } & \multicolumn{2}{|c|}{$\begin{array}{c}\text { Period I } \\
1997-1999\end{array}$} & \multicolumn{2}{|c|}{$\begin{array}{c}\text { Period II } \\
\text { 2000-2002 }\end{array}$} & \multirow[t]{2}{*}{ index } & \multirow[t]{2}{*}{$P$} \\
\hline & frequency & $\%$ & frequency & $\%$ & & \\
\hline Pelvic injuries & 3 & 13.6 & 3 & 17.6 & 1.29 & 0.731 \\
\hline Contusions of the spine and limbs & 2 & 9.1 & 0 & 0.0 & - & - \\
\hline Paresis of the hind limbs & 5 & 22.7 & 4 & 23.5 & 1.04 & 0.953 \\
\hline Limb injuries & 8 & 36.4 & 7 & 41.2 & 1.13 & 0.759 \\
\hline Joint and claw inflammations & 1 & 4.5 & 3 & 17.6 & 3.88 & 0.181 \\
\hline Selection and technopathy & 0 & 0.0 & 0 & 0.0 & - & - \\
\hline Cachexia and GIT disorders & 1 & 4.5 & 0 & 0.0 & - & - \\
\hline Ataxia & 2 & 9.1 & 0 & 0.0 & - & - \\
\hline Tetany & 0 & 0.0 & 0 & 0.0 & - & - \\
\hline Circulation disorders & 0 & 0.0 & 0 & 0.0 & - & - \\
\hline Post-partum complications & 0 & 0.0 & 0 & 0.0 & - & - \\
\hline Other & 0 & 0.0 & 0 & 0.0 & - & - \\
\hline Total & 22 & 100.0 & 17 & 100.0 & & \\
\hline Locomotor apparatus total & 19 & 86.4 & 17 & 100.0 & 1.16 & 0.113 \\
\hline
\end{tabular}

Legend: $P=$ statistical significance; Index $=$ the ratio of the relative frequencies of the incidence of emergency slaughters due to immobility for the $1^{\text {st }}$ period (1997 to 1999) and the $2^{\text {nd }}$ period (2000 to 2002); - = a very small frequency was found to be sufficient for the calculation of the index and the statistical significance

\section{Discussion}

The results show that the most important causes of emergency slaughters in cattle due to immobility reasons are to be found in damage to the locomotor apparatus while it is most prominent in bulls, then in heifers, calves and last in cows. These results are in accord with the findings that Broom and Corke (2002) as well as Bergstein (2001) 
Table 5

The trend of the incidence of the individual causes of emergency slaughters in calves due to immobility

\begin{tabular}{|c|c|c|c|c|c|c|}
\hline \multirow[t]{2}{*}{ Calves } & \multicolumn{2}{|c|}{$\begin{array}{c}\text { Period I } \\
1997-1999\end{array}$} & \multicolumn{2}{|c|}{$\begin{array}{c}\text { Period II } \\
2000-2002\end{array}$} & \multirow[t]{2}{*}{ index } & \multirow[t]{2}{*}{$P$} \\
\hline & frequency & $\%$ & frequency & $\%$ & & \\
\hline Pelvic injuries & 2 & 11.1 & 0 & 0.0 & - & - \\
\hline Contusions of the spine and limbs & 1 & 5.6 & 0 & 0.0 & - & - \\
\hline Paresis of the hind limbs & 3 & 16.7 & 2 & 40.0 & 2.40 & 0.263 \\
\hline Limb injuries & 5 & 27.8 & 1 & 20.0 & 0.72 & 0.726 \\
\hline Joint and claw inflammations & 4 & 22.2 & 1 & 20.0 & 0.90 & 0.915 \\
\hline Selection and technopathy & 1 & 5.6 & 0 & 0.0 & - & - \\
\hline Cachexia and GIT disorders & 0 & 0.0 & 0 & 0.0 & - & - \\
\hline Ataxia & 1 & 5.6 & 1 & 20.0 & 3.60 & 0.311 \\
\hline Tetany & 0 & 0.0 & 0 & 0.0 & - & - \\
\hline Circulation disorders & 1 & 5.6 & 0 & 0.0 & - & - \\
\hline Post-partum complications & 0 & 0.0 & 0 & 0.0 & - & - \\
\hline Other & 0 & 0.0 & 0 & 0.0 & - & - \\
\hline Total & 18 & 100.0 & 5 & 100.0 & & \\
\hline Locomotor apparatus total & 15 & 83.3 & 4 & 80.0 & 0.96 & 0.862 \\
\hline
\end{tabular}

Legend: $P=$ statistical significance; Index $=$ the ratio of the relative frequencies of the incidence of emergency slaughters due to immobility for the $1^{\text {st }}$ period (1997 to 1999) and the $2^{\text {nd }}$ period (2000 to 2002); - = a very small frequency was found to be sufficient for the calculation of the index and the statistical significance

and Logue et al. (1993) presented who consider the limb disorders the most frequent causes of the limitation of mobility in cattle. The finding that the most common causes of emergency slaughters due to immobility in cattle are the locomotor apparatus diseases is in accord with the conclusions of Večerek et al. (2003a). Diseases of the locomotor apparatus thus reduce the total count of cattle carcasses suitable for consumption at the slaughter selection procedure (Kozák et al. 2002), are the lowest in comparison to other food animal species. The high incidence of diseases of the locomotor apparatus is also in accord with the findings of Večerek et al. (2003b) and Kozák et al. (2003) about the frequency of slaughter findings of non-infectious diseases being higher than in the case of infectious diseases.

The trends of development of emergency slaughters due to immobility show that in cows, the causes of immobility lie in damage to the locomotor apparatus, namely in the limb injuries and joint and claw inflammations and that they have an increasing trend. In heifers, the causes are to be found mostly in the limb injuries and joint and claw inflammations. In bulls, they are above all in joint and claw inflammations and pelvic injuries. On the contrary, other causes of immobility are in the general bad condition of the organism that is related to the insufficient care rather than unsuitable handling (namely ataxia and GIT disorder, circulation disorders, post-delivery complications) display a decreasing trend in cows, heifers and bulls. From the above mentioned facts it follows that the handling of cows, heifers and bulls at farms during transport and at slaughter facilities before slaughter is worsening. This results in damage of the locomotor apparatus.

To reduce the frequency of emergency slaughters due to immobility in cattle, measures have to be taken to limit all damage to animals before and during transport, and at slaughter. It is essential to educate well all animal handlers. Thus also the numbers of cattle carcasses and animal organs unsuitable for consumption (Večerek et al. 2003c, 2004) will be reduced. 


\section{Nutné porážky skotu z důvodu nepohyblivosti}

Cílem práce bylo určit nejčastější příšiny a trend ve vývoji nutných porážek u skotu z důvodu nepohyblivosti. Ve vybraném provozu pro porážení jatečných zviŕat v oblasti jižních Čech byly v období let 1997 až 2002 sledovány nutné porážky u krav, jalovic, býků a telat $\mathrm{z}$ důvodu jejich nepohyblivosti. Byly zaznamenávány četnosti pro jednotlivé př́činy těchto nutných porážek. Nejčastějšími př́šinami nutných porážek z důvodu nepohyblivosti bylo poškození pohybového aparátu, které činilo u krav 72,2 \%, u jalovic 87,2 \%, u býků $92,4 \%$, u telat $82,5 \%$ a dále bylo zjištěno, že nejčastějšími přičinami jsou poranění končetin, záněty kloubů a paznehtů, poranění pánve a parézy pánevních končetin. Z hlediska trendů vývoje byl zaznamenán u krav vzestup pro poruchy pohybového aparátu u krav (index 1,21), u jalovic (index 1,13), a u býkủ (index 1,16). Tento vzestup byl zjištěn statisticky významný u krav $(P=0,001)$, u jalovic a býků byl tento vzestup statisticky nevýznamný. Jiné př́iciny nutných porážek z důvodu nepohyblivosti spočívající v celkovém onemocnění organismu, vykazovaly u krav, jalovic a býků klesající trend. U telat vzestup pro poruchy pohybového aparátu zaznamenán nebyl (index 0,96). Z uvedeného vyplývá, že poruchy pohybového aparátu jsou hlavní př́ićinou nutných porážek $z$ důvodu nepohyblivosti u skotu.

\section{References}

BERGSTEN, C 2001: Effects of conformation and management system on hoof and leg diseases and lameness in dairy cows. Vet Clin North Am Food Anim Pract 17: 1-23

BISS, ME, ALLE, MR, MADIE, P, HATHAWAY, SC 1994: Lesions in the carcasses and viscera of very young slaughter calves condemned at post-mortem meat inspection. N Z Veter J 42: 12-127

BROOM, DM, CORKE, M J 2002: Effects of disease on farm animal welfare. Acta Vet Brno 71: 133-136

GIACCONE, V, JULINI, M, GILLI, M, GILI, S, RATTAZZI, C, CACCIATORE, A 1994: Incidence of hepatic lesions at meat inspections. Ind Aliment - Italy 33: 1245-1247

JULINI, M 1993: The slaughterhouse as an epidemiologic observatory. Ind Aliment - Italy 32: 1075-1078

LOGUE, DN, OFFER, JE, KEMPSON, SA 1993: Lameness in dairy - cattle. Irish Vet J 46: 47-58

KOZÁK, A, VEČEREK, V, STEINHAUSEROVÁ, I, CHLOUPEK, P, PIŠTĚKOVÁ, V 2002: Results of slaughterhouse carcass classification (capable for human consumption, capable for processing and condemned in selected species of food animals. Vet Med - Czech 47: 26-31

KOZÁK, A, VEČEREK, V, CHLOUPEK, P, TREMLOVÁ, B, MALENA, M 2003: Veterinary meat inspection of pig carcasses in the Czech Republic during the period of 1995-2002. Vet Med - Czech 48: 207-213

VEČEREK, V, BARTOŠEK, B, KOZÁK, A, CHLOUPEK, P, PIŠTĚKOVÁ, V 2003a: Emergency slaughter of cattle in the Czech Republic: the most frequent cause and their occurrence in the period of $1997-2002$. Acta Vet Brno 72: 445-452

VEČEREK, V, KOZÁK, A, MALENA, M, TREMLOVÁ, B, CHLOUPEK, P 2003b: Veterinary meat inspection of bovine carcasses in the Czech Republic during the period of 1995 - 2002. Vet Med - Czech 48: 183-189

VEČEREK, V, KOZÁK, A, MALENA, M, CHLOUPEK, P, PIŠTĚKOVÁ, V 2003c: Viscera of slaughtered ruminants and potential threats to human health in the Czech Republic. Acta Vet Brno 72: 631-638

VEČEREK, V, KOZÁK, A, MALENA, M, CHLOUPEK, P, PIŠTËKOVÁ, V 2004: Organs of slaughter pigs as a source of potential risk for human health in the Czech Republic during the years 1995-2002. Vet Med - Czech 49: $75-78$ 